\title{
KEWENANGAN PTUN DALAM MENYELESAIKAN SENGKETAPERBUATAN MELANGGAR HUKUM OLEH PEMERINTAH (ONRECHMATIGE OVERHEIDSDAAD)
}

\author{
Bambang Arwanto ${ }^{1}$ \\ Program Studi Magister Kenotariatan \\ Fakultas Hukum \\ Universitas Narotama Surabaya \\ Email : bambang.arwanto@narotama.ac.id
}

\begin{abstract}
ABSTRAK
Jurnal ini berjudul Kewenangan PTUN Dalam Menyelesaikan Sengketa Perbuatan Melanggar Hukum Oleh Pemerintah (Onrechmatige Overheidsdaad)" berfokus pada " Objektum Litis dan Tolok ukur pengujian Perbuatan Melanggar Hukum Oleh Pemerintah (Onrechmatige Overheidsdaad)oleh PTUN.Berdasarkan hasil penelitian ketentuan Pasal 85 objek kewenangan PTUN adalah KTUN maupun tindakan faktual (feitelijke handelingen) yang dapat menyebabkan Onrechmatige Overheidsdaad. Pengertian "dilimpahkan" itu hanya terbatas pada pemeriksaan, pemutusan dan penyelesaian gugatan/tuntutan yang bener-benar menjadi wewenang PTUN, sedangkan mengenai gugatan/tuntutan yang bersifat murni hukum perdata diajukan ke Peradilan Umum. Pengujian Onrechmatige Overheidsdaad oleh PTUN berdasarkan pada aspek "rechmatigheids van bestuur", diukur berdasarkan keabsahan wewenang, prosedur dan substansi yang berdasar pada peraturan perundang undangan yang berlaku dan AUPB.
\end{abstract}

Kata Kunci: Kewenangan, PTUN, Onrechmatige Overheidsdaad.

1 Dosen Fakultas Hukum Narotama 


\section{A. PENDAHULUAN}

\section{Latarbelakang}

Sebelum dibentuknya UU AP, sistem tanggung gugat terhadap pemerintah terkait dengan tanggung jawab hukum (control segi hukum) terhadap tindak pemerintahan (bestuur handelingen) dikategorikan dalam dua jenis tanggung gugat, yaitu tanggung gugat terhadap KTUN yang merugikan warga masyarakat dan tanggung gugat terhadap tindakan pemerintah yang dikategorikan sebagai perbuatan melanggar hukum oleh pemerintah (Onrechmatige

Overheidsdaad).

Perbedaan terhadap dua jenis system tanggung gugat pemerintah ini berimplikasi kepada lingkup kompetensi pengadilan dalam menguji dan menetapkan gugatan terhadap pemerintah. Dimana gugatan terhadap terhadap KTUN yang dikeluarkannya pemerintah menyebabkan kerugian pada warga masyarakat diajukan melalui PTUN sedangkan untuk perbuatan pemerintah yang merugikan warga masyarakat atas dasar Onrechmatige Overheidsdaad disalurkan melalui Peradilan Umum (Pengadilan Negeri).
Setelah dibentuknya UUAP, sengketa Onrechmatige Overheidsdaad dialihkan dari Peradilan Umum kepada PTUN. Sebagaimana dinyatakan dalam ketentuan Pasal 85 UUAP bahwaPengajuan gugatan sengketa Administrasi Pemerintahan yang sudah didaftarkan pada pengadilan umum tetapi belum diperiksa, dengan berlakunya Undang-Undang ini dialihkan dan diselesaikan oleh Pengadilan, ${ }^{2}$ dan Pengajuan gugatan sengketa Administrasi Pemerintahan yang sudah didaftarkan pada pengadilan umum dan sudah diperiksa, dengan berlakunya UndangUndang ini tetap diselesaikan dan diputus oleh pengadilan di lingkungan peradilan umum dimana Putusan pengadilan sebagaimana dimaksud dilaksanakan oleh pengadilan umum yang memutus.Ketentuan peralihan tentang kewenangan PTUN menyelesaikan sengketa Onrechmatige Overheidsdaad dalam UUAP, sebelumnya telah diatur dalam ketentuan Pasal 142 UU PTUN sebagaimana diatur pula dalam Surat Edaran Mahkamah Agung Nomor 1 Tahun 1991 Tentang Petunjuk 2dalam UUAP yang dimaksud Pengadilan adalah PTUN. 
Pelaksanaan Ketentuan Peralihan Undang Undang Nomor 5 Tahun 1986, yang menyatakan bahwa Sengketa Tata Usaha Negara yang pada saat terbentuknya Pengadilan menurut Undang-undang ini belum diputus oleh Pengadilan di lingkungan Peradilan Umum tetap diperiksa dan diputus oleh Pengadilan di lingkungan Peradilan Umum dan Sengketa Tata Usaha Negara yang pada saat terbentuknya Pengadilan menurut Undang-undang ini sudah diajukan kepada Pengadilan di lingkungan Peradilan Umum tetapi belum diperiksa, dilimpahkan kepada Pengadilan di lingkungan Peradilan Tata Usaha Negara.

Atas dasar ketentuan peralihan sebagaimana disebutkan dalam Ketentuan Pasal 85 UUAP diatas yang sebelumnya selaras dengan Pasal 142 UU PTUN sebagaimana diatur pula dalam Surat Edaran Mahkamah Agung Nomor 1 Tahun 1991 Tentang Petunjuk Pelaksanaan Ketentuan Peralihan Undang Undang Nomor 5 Tahun 1986, menjadi dasar penulisan Jurnal ini dengan Judul Kewenangan PTUN Dalam Menyelesaikan Sengketa Perbuatan Melanggar Hukum Oleh Pemerintah (Onrechmatige Overheidsdaad) dengan pokus kajian tentang perubahanobjektum litis kewenangan PTUN dalam menyelesaikan sengketa perbuatan melanggar hukum oleh pemerintah (onrechmatige overheidsdaad) dan tolok ukur pengujian sengketa perbuatan melanggar hukum oleh pemerintah (onrechmatige overheidsdaad) oleh PTUN.

\section{Rumusan Masalah}

a. PerubahanObjektum Litis kewenangan PTUN dalam menyelesaikan sengketa perbuatan melanggar hukum oleh pemerintah (Onrechmatige Overheidsdaad).

b. Tolok ukur pengujian sengketa perbuatan melanggar hukum oleh pemerintah (Onrechmatige Overheidsdaad) oleh PTUN.

\section{Tujuan Penelitian}

Penelitian ini bertujuan untuk menganalisis perubahan Objektum Litiskewenangan PTUN dalam menyelesaikan sengketa perbuatan melanggar hukum oleh pemerintah (Onrechmatige Overheidsdaad) dan Tolok ukur pengujian sengketa perbuatan melanggar hukum oleh pemerintah 
(Onrechmatige Overheidsdaad) oleh PTUN.

\section{Manfaat Penelitian}

Dari segi teoritik penelitian ini diharapkan dapat bermanfaat bagi pengembangan ilmu hukum, khususnya hukum Administrasi. Dari segi praktis, diharapkan dapat dijadikan sebagai dasar pedomanbagi Pemerintah, Warga Masyarakat dan PTUN terhadap kompetensi PTUN dalam menyelesaikan sengketa Onrechmatige Overheidsdaad.

\section{Metode Penelitian}

Penelitian ini merupakan penelitian hukum normatif, dengan menggunakan metode penelitian hukum yang bertujuan untuk mencari pemecahan atas isu hukum yang timbul didalamnya. Sehingga hasil yang akan dicapai adalah memberikan preskripsi mengenai apa yang seyogyanya atas isu hukum yang diajukan. Pendekatan yang digunakan adalah pendekatan perundang-undangan (statute approach), pendekatan konseptual (conceptual approach), dan pendekatan historis(historical

approach). ${ }^{3}$ Metode analisis bahan hukum didasarkan pada bahan hukum primer berupa perundanganundangandikumpulkan dengan metode inventarisasi dan kategorisasi. Bahan hukum sekunder dikumpulkan dengan sistim kartu catatan (card sistem), baik dengan kartu ikhtisiar (memuat ringkasan tulisan sesuai aslinya, secara garis besar dan pokok gagasan yang memuat pendapat asli penulis); Kartu kutipan (digunakan untuk memuat catatan pokok permasalahan); serta kartu ulasan (berisi analisis dan catatan khusus penulis).

B. PEMBAHASAN

1. PerubahanObjektum Litis Kewenangan PTUN dalam Menyelesaikan Sengketa Perbuatan Melanggar Hukum Oleh Pemerintah (Onrechmatige Overheidsdaad).

a. Tinjauan Historis Kewenangan Peradilan Umum dalam Menyelesaikan Sengketa Onrechmatige Overheidsdaad.

Dalam bukunya yang berjudul "Perlindungan Hukum Bagi Rakyat Di Indonesia" Philipus M.

3Peter Mahmud Marzuki, Penelitian Hukum, Kencana Prenada Media Group, Jakarta, 2005,h. 113 
Hadjon mengkritisi beberapa alasan yang dijadikan dasar hukum oleh Peradilan Umum untuk menyatakan dirinya kompeten menangani gugatan terhadap pemerintah atas dasar onrecmatige overheidsdaad dari putusan-putusan yang pernah ada yakni dengan menunjuk pada Pasal 2 Wet op de Rechtelijke Organisatie (RO) sebagai dasar hukum, belum adanya peradilan administrasi dan menyatakan sebagai dasar hukum adalah yurisprudensi, ${ }^{4}$ menurutnya:

a. Tidak tepat bagi pengadilan di Indonesia dalam hal menyatakan kewenangannya mengadili kasus gugatan terhadap pemerintah mendasarkan diri pada ketentuanPasal 2 RO..., dikarenakan struktur tidak ada hubungan apapun dengan (organisasi maupun fungsional) dengan Hoge Raad, misalnya putusan pengadilan yang menunjuk Pasal 2 RO sebagai dasar kewenangan misalnya Putusan Pengadilan Negeri Jakarta No. 1278/1953 dalam perkara 'Septheno'.

b. Mengenai, belum adanya Peradilan Administrasi, misalkan pada Putusan

4Philipus M. Hadjon, Perlindungan Hukum Bagi Rakyat di Indonesia, Peradaban, Surabaya, 2007,h.106-109
MA Nomor 421

K/Sip/1969 tanggal 22 November 1969, dalam kasus Oentoeng Sediatmo melawan Kejaksaan Agung, dalam pertimbangan putusan tersebut menyatakan "sebelum ada UU tentang Peradilan Tata Usaha Negara, maka Pengadilan Negeri berwenang untuk memeriksa dan memutus gugatan terhadap Pemerintah RI". Pertimbangan Putusan MA tersebut menegaskan bahwa onrechmatige oveirheidsdaad

sesungguhnya termasuk dalam sengketa administrasi dan merupakan kompetensi peradilan administrasi;

c. Yurisprudensi sebagai dasar hukum bagi pengadilan negeri dalam menangani sengketa perbuatan melanggar hukum oleh pemerintah terutama pada putusan MA No. $981 \quad \mathrm{~K} / \mathrm{Sip} / 1972$ tanggal 31 Oktober 1974 dalam kasus Jong Kong Seng melawan Pemerintah Daerah Kabupaten Panarukan cs. yang berbunyi "Berdasarkan yurisprudensi perbuatan melanggar hukum yang dilakukan oleh pejabat negara tunduk pada yurisdiksi Pengadilan Umum”. Putusan MA 
tersebut dengan merujuk kepada yurisprudensi Mahkamah Agung Republik Indonesia, Nomor 838 K/Sip/1970 tanggal 20 Januari 1971, dalam kasus W. Josopandojo melawan Pemerintah DKI Jakarta Raya dan Ali Husien Tajibalay. Hal menarik dalam putusan Mahkamah Agung Republik Indonesia, Nomor 838 $\mathrm{K} / \mathrm{Sip} / 1970$ tanggal 20 Januari 1971, yang menjadi yurisprudensi MA adalah penentuan kriteria onrechmatige

overheidsdaad di Indonesia dinilai dengan/berdasarkanundan g-undang dan peraturan formal yang berlaku, dan selain itu dengan kepatutan dalam masyarakat yang seharusnya dipatuhi oleh Pemerintah.

Kewenangan Peradilan Umum dalam menangani sengketa onrechtmatige overheidsdaaddengan berdasar pada beberapa Putusan Mahkamah Agung diatas diperkuat lagi setelah dibentuknya UU Nomor 5 Tahun 1986 Tentang Peradilan Tata Usaha Negara, sebagaimana telah diubah dengan UU Nomor 9 Tahun 2004 jo. UU Nomor 51 Tahun 2009, dimana PTUN hanya memiliki kompetensi absolute memeriksa sengketa administrasi yang ditimbulkan oleh KTUN sedangkan untuk sengketa antara pemerintah dengan rakyat dari jenis tindakan pemerintah lainnya diluar KTUN disalurkan melalui gugatan Onrechmatige Overheidsdaad sebagaimana dijelaskan dalam Penjelasan Umum UU Nomor 5 Tahun 1986 menyatakan bahwa sengketa sengketa administrasi atau gugatan terhadap pemerintah yang tidak termasuk kompetensi PTUN, termasuk kompetensi Peradilan Umum.

Fockema Andrea dan Logemenn ${ }^{6}$ sendiri menyatakan ketika pemerintah melanggar peraturan undang-undang, pemerintah dianggap telah melakukan tindakan yang tidak sah, sekalipun ketentuan yang dilangggar bersifat hukum publik, dan tidak dapat dianggap sebagai pelanggaran hukum subyektif

5Djenal Hoesen Koesoemahatmadja, Pokok-Pokok Hukum Tata Usaha Negara, Bandung, Citra Aditya Bakti, 1990, h. 45

6 Kuntjoro Purbobronoto, Beberapa Catatan Hukum Tata Pemerintahan Dan Peradilan Administrasi Negara, Cet ke-2, Alumni Bandung, 1978, h. 132 
(administrasi negara tidak mungkin dapat berlaku norma yang sama yang berlaku untuk seorang swasta). Artinya kedua pakar tersebutkeberatan apabila diberlakukan norma yang sama atau saluran penegakan hukum yang sama terhadap pelanggaran hukum yang dilakukan oleh badan/pejabat pemerintahan dengan yang berlaku untuk seorang swasta mengingat kedudukan khusus badan/pejabat pemerintahan dalam melaksanakan fungsinya menjaga dan memajukan kesejahteraan umum. Contoh kongkret suatu perbuatan melanggar hukum oleh pemerintah (onrechtsmatige overheidsdaad) dapat dijumpai dalam ketentuan Pasal 24 dan Pasal 273 Undang-Undang No.22 Tahun 2009 tentang Lalu-lintas dan Angkutan Jalan. Mendasarkan pemerintah sebagai pihak penyelenggara jalan wajib segera dan patut untuk memperbaiki jalan yang rusak yang dapat mengakibatkan kecelakaan lalu lintas dan/atau dalam hal belum dapat dilakukan perbaikan jalan yang rusak penyelenggara jalan wajib memberi tanda atau rambu pada jalan yang rusak untuk mencegah terjadinya kecelakaan lalu lintas. Apabila aturan tersebut tidak diindahkan dan sebagai penyebab terjadinya kecelakaan dan menyebabkan kerugian pada warga masyarakat maka berdasarkan ketentuan Pasal 273 ayat (1),(2),(3) dan (4) maka pemerintah sebagai penyelenggara negara akan dijatuhi sanksi pidana penjara minimal 6 bulan dengan maksimal 6 tahun penjara atau dikenakan denda paling banyak Rp.120.000.000,00 (seratus dua puluh juta rupiah).

Apabila ditinjau berdasarkan konsep hukum administrasi dalam substansi Pasal 24 dan 273 Undang Undang Nomor 22 Tahun 2009 di atas terutama mengatur tentang kewajiban hukum terhadap pelaksanaan urusan pemerintah di bidang lalu lintas badan/pejabat pemerintah yang berwenang dituntut untuk senantiasa menyediakan dan memperbaiki akses lalu lintas dengan baik dan aturan tersebut secara tegas mengatur upaya hukum yang diberikan kepada seseorang yang merasa dirugikan (kecelakaan) karena kesengajaan atau kelalaian badan/pejabat pemerintah dalam arti melakukan atau tidak 
dilakukannya suatu perbaikan dan/atau penerangan jalan raya penyediaan pasilitas jalan raya yang buruk oleh pemerintah akibatnya pemerintah wajib mempertanggungjawabkan terhadap pasilitas negara yang menyebabkan kerugian kepada rakyat.

$$
\text { Philipus M. Hadjon }
$$

menyatakan ada beberapa hal yang tidak menunjang efektifitas penanganan perkara-perkara onrecmatige oveiheidsdaad oleh Peradilan Umum yaitu meliputi aspek dasar hukum, perkembangan criteria perbuatan melanggar hukum oleh pemerintah, spesialisasi hakim, kuantitas perkara, keseimbangan antara hak dan kewajiban, keserasian hubungan antara pemerintah berdasarkan asas kerukunan dan Prinsip penyelesaian sengketa secara musyawarah dan peradilan merupakan sarana terakhir. ${ }^{7}$ Serta pada prinsipnya bahwa semua tindakan pemerintahan yang dilakukan oleh pemerintah sejatinya berdasar pada kewenangan khusus (hukum administrasi) ditujukan untuk kepentingan umum dalam penyelenggaraan pemerintahan demi terealisasinya tujuan pembangunan nasional.

Menurut Paulus Effendi Lotulung, penanganan perkara Onrechtmatige Overheidsdaad sejatinya merupakan kompetensi PTUNbukan kompetensi Pengadilan Umum dikarenakan sejatinya semua sengketa administrasi pemerintahan yang disebabkan oleh berbagai jenis tindakan

pemerintahan (bestuurshandelingen) baik itu KTUN maupun tindakan faktual (feitelijke handelingen) termasuk Onrechmatige Overheidsdaad menjadi kompetensi PTUN, hal ini didasarkan sebelumnya dalam dokumen yang bersifat naskah akademik penyusunan RUU tentang peradilan administrasi tahun 1980 yang disusun oleh tim ahli dari BPHN (Badan Pembinaan Hukum Nasional) Departemen Kehakiman telah diusulkan dan direkomendasikan bahwa yuridiksi atau kompetensi PTUN itu sangat luas, yaitu meliputi tentang sengketa KTUN maupun mencakup semua perbuatan faktual pemerintah yang berdasarkan dan melanggar hukum publik yang

7Ibid., h. 131-140 
menimbulkan kerugian bagi rakyat dan pencari keadilan. ${ }^{8}$

Upaya untuk meletakkan obyek sengketa yang timbul dalam administrasi pemerintahan atas dasar onrechmatige overheidsdaad tidak dibarengi dengan dukungan politik hukum yang dominan pada tahun 1986 sangat dipengaruhi oleh pertimbangan sepihak dari pemerintah bahwa sebagai lembaga peradilan baru, PTUN tidak perlu diberi kewenangan yang luas terlebih dahulu untuk menghindari terjadinya kegoncangankegoncangan. Oleh karena itu PTUN hanya diberikan kewenangan untuk mengadili KTUN yang bersifat kongkret individual dan final, sehingga belum mampu mengakomodir atau memungkinkan dibentuknya PTUN yang mempunyai yuridiksi yang luas terutama ketika ditetapkannya UU No 5 Tahun 1986 Tentang Peradilan Tata Usaha Negara.

Pada saat UU Nomor 5 Tahun 1986 telah direvisi dengan UU Nomor 9 tahun 2004 kompetensi PTUN tetap

8Paulus Effendi Lotulung, Lintasan Sejarah Dan Gerak Dinamika Peradilan Tata Usaha Negara (PERATUN), Salemba Humanika, Jakarta, 2013, h. 81-82 mengadili sengketa TUN yang lahir dari KTUN, bahkan revisi kedua dengan UU Nomor 51 Tahun 2009 tetap tidak mengalami perubahan.Pemberian kewenangan yang terbatas kepada PTUN itu sejatinya justru mengingkari dasar filosofi dibentuknya PTUN itu sendiri, untuk mengambil alih fungsi Peradilan Umum dalam mengadili onrechtmatige overheidsdaad. Seharusnya PTUN diberikan kewenangan sesuai dengan filosofi pembentukannya, apalagi dengan perkembangan ketatanegaraan saat ini, khususnya dalam dunia peradilan Indonesia, alasan pemerintah terhadap ketidaksiapan PTUN menerima kewenangan yang luas tentu saja tidak dapat dipertahankan. Usia PTUN yang kini sudah mencapai 32 tahun (19862018) tentu sudah sangat matang apabila diberikan kewenangan mengadili semua sengketa administrasi. PTUN telah mengalami perkembangan baik dari jumlah pengadilannya maupun kualitas sumber dayanya yang meliputi hakimnya, pegawainya atau sarana dan prasarana lainnya sehingga dijadikan 
dasar pertimbangan perluasan kompetensi PTUN.

b. Objektum KompetensiPTUNDalam Menyelesaikan

Onrechmatige OverheidsdaadSetelah Berlakunya UUAP.

Sebelum ditetapkannya UU AP, kompetensi PTUN diatur dalam ketentuan Pasal 47 UU Nomor 5 Tahun 1986 yang menyatakan bahwa pengadilan bertugas dan berwenang memeriksa, memutus, dan menyelesaikan sengketa tata usaha negara. Sengketa yang dimaksud dalam Pasal 47 diatas sebelumnya ditegaskan dalam Pasal 1 angka 4 UU Nomor 5 Tahun 1986 Jo UU Nomor 9 Tahun 2004, yang menyatakan bahwa:

"Sengketa tata usaha negara (sengketa administrasi negara) adalah sengketa yang timbul dalam bidang tata usaha negara (administrasi negara) antara orang atau badan hukum perdata dengan badan atau pejabat tata usaha negara administrasi negara) baik di pusat maupun di daerah, sebagai akibat dikeluarkannya keputusan tata usaha negara (keputusan administrasi termasuk berdasarkan negara), kepegawaian peraturan perundang-undangan yang berlaku."

Selanjutnya Pasal 1 angka 3 UU Nomor 5 Tahun 1986, KTUN adalah suatu penetapan tertulis yang dikeluarkan oleh badan atau pejabat TUN yang berisisi tindakan hukum TUN yang berdasar pada peraturan perundang undangan yang berlaku bersifat kongkret, individual dan pinal yang menimbulkan akibat hukum bagi seseorang atau badan hukum perdata. Pasal 3 ayat (1) menyatakan bahwa apabila badan atau pejabat TUN tidak mengeluarkan keputusan sedangkan hal itu menjadi kewajibannya maka hal itu disamakan dengan KTUN (KTUN fiktif). Juga keputusan negatif yaitu jika suatu badan atau pejabat TUN tidak mengeluarkan keputusan yang dimohon sedangkan jangka waktu yang ditentukan telah lewat, maka badan atau pejabat TUN dianggap telah menolak mengeluarkan keputusan yang dimaksud. Meskipun demikian tidak sembarang KTUN dapat menjadi kompetensi PTUN sebagaima pengecualian KTUN 
dikmaksudkan dalam ketentuan Pasal 2 dan Pasal 49 UU Peratun.

$$
\text { Pasal } 2 \text { UU Peratun }
$$

menyatakan hal yang dikecualikan atau yang tidak menjadi kewenangan untuk diadili oleh hakim PTUN walaupun itu merupakan KTUN:

a. Keputusan TUN yang merupakan perbuatan hukum perdata;

b. Keputusan TUN yang merupakan pengaturan yang bersifat umum;

c. Keputusun TUN yang masih memerlukan persetujuan;

d. Keputusan TUN yang dikeluarkan berdasarkan ketentuan KUHP dan KUHAP atau peraturan perundang undangan lain yang bersifat hukum pidana.

e. Keputusan TUN yang dikeluarkan atas dasar hasil pemeriksaan badan peradilan berdasarkan ketentuan peraturan perundang undangan yang berlaku;

f. Keputusan TUN mengenai tata usaha tentara nasional indonesia;

g. Keputusan komisi pemilihan umum, baik dipusat maupun di daerah mengenai hasil pemilihan umum.
Dalam ketentuan Pasal 49 UU Peratun, PTUN tidak berwenang untuk memeriksa, dan memutus sengketa TUN tertentu apabila KTUN tersebut dikeluarkan:

a. Dalam waktu perang, keadaan bahaya, keadaan bencana alam atau keadaan luar biasa yang membahayakan berdasarkan peraturan perundang undangan yang berlaku;

b. Dalam keadaan mendesak untuk kepentingan berdasarkan peraturan perundang undangan yang berlaku.

Sebagaimana disebutkan pada pembahasan sebelumnya bahwa ketentuanPasal 85 UUAP mengadakan peralihan kewenangan penyelesaian sengketaOnrechmatige Overheidsdaad dari Peradilan Umum kepada PTUN. Yang mana sesungguhnya telah diatur dalam ketentuan Pasal 142 UU PTUN sebagaimana diatur pula dalam dalam Surat Edaran Mahkamah Agung Nomor 1 Tahun 1991 Tentang Petunjuk Pelaksanaan Ketentuan Peralihan Undang Undang Nomor 5 Tahun 1986. Dalam Surat Edaran Mahkamah Agung Nomor 1 Tahun 
1991 Tentang Petunjuk Pelaksanaan

Ketentuan Peralihan Undang Undang

Nomor 5 Tahun 1986 ditegaskan

bahwa ketentuan Peralihan

penyelesaian sengketa Onrechmatige

Overheidsdaad dari Peradilan Umum

kepada PTUN hanya berkaitan kepada

Onrechmatige Overheidsdaad yang disebabkan oleh KTUN dengan pembatasan dalam Pasal 2 dan Pasal 49 UUPeratun yang merugikan warga masyarakat. Dimana sebelumnya termasuk kedalam kompetensi Peradilan Umum atas dasar perkara Onrechmatige overhaidsdaad yang kemudian dialihkan menjadi kompetensi PTUN berdasarkan UUPeratun. Sedang mengenai tuntutan ganti ruginya atau tututan yang lainnya yang bersifat perselisihan murni hukum perdata tetap merupakan wewenang Peradilan Umum dan hal itu baru dapat diputuskan oleh Peradilan Umum setelah ada putusan mengenai sah tidaknya pencabutan KTUN tersebut oleh PTUN setempat sampai nantinya memperoleh kekuatan hukum tetap.

Setelah dibentuknya UUAP objektum litis kewenangan PTUN dalam menyelesaikan sengketa perbuatan melanggar hukum oleh Pemerintah (Onrechtsmatige Overheidsdaad) tidak lagi atas dasar KTUN berdasarkan UUPeratun, namun KTUN berdasarkan UUAP sebagaimana dimaksud dalam ketentuan Pasal 87 UUAP mengenai perluasan elemen KTUN, yakni:

a. penetapan tertulis yang juga mencakup tindakan faktual $;$

b. Keputusan Badan dan/atau Pejabat Tata Usaha Negara di lingkungan eksekutif, legislatif, yudikatif, dan penyelenggara negara lainnya;

\begin{abstract}
9Secara teoritis beberapa pakar hukum administrasi keberatan apabila tindakan faktual dimaknai sebagai KTUN dikarenakan dua jenis tindakan pemerintahan (bestuurs handelingen) tersebut berbeda, namun politik hukum yang dibangun dalam UUAP berupaya memberikan kepastian perlindungan hukum kepada warga masyarakat dan pejabat pemerintah terhadap segala tindakan pemerintahan (bestuurs handelingen) yang merugikan warga masyarakat, karena sebelum dibentuknya UUAP, kerugian warga masyarakat yang disebabkan oleh tindakan factual (feitelijke handelingen) yang tidak berdasar KTUN versi UUPeratun tidak dapat dilakukan upaya hukum melalui PTUN sehingga menjadi kewenangan Peradilan Umum. Sehingga dengan dibentuknnya UUAP, dilakukannya perluasan KTUN sebagaimana dimaksudkan dalam Pasal 87 sehingga KTUN berdasarkan UUAP dapat mengakomodir/sebagai dasar kewenangan dilakukannya tindakan faktual pemerintah (feitelijke handelingen) yang merugikan warga masyarakat dan selanjudnya sebagai perluasan objektum litis kompetensi PTUN.
\end{abstract}


c. berdasarkan ketentuan perundang-undangan dan AUPB;

d. bersifat final dalam arti lebih luas;

e. Keputusan yang berpotensi menimbulkan akibat hukum; dan/atau

f. Keputusan yang berlaku bagi Warga Masyarakat.

Berdasarkan ketentuan tersebut objek kewenangan PTUN adalah tindakan pemerintahan (bestuurshandelingen) yang tergolong KTUN (termasuk didalamnyakeputusan Diskresi (tidak tertulis/berbentuk tindakan pisik) yang mendasari dilakukannya tindakan faktual (feitelijke handelingen) yang menyebabkan Onrechmatige Overheidsdaadsehingga menimbulkan kerugian bagi warga masyarakat.

Sehingga pengertian "dilimpahkan/dialihkan" dalam ketentuan Pasal 85 UUAP itu hanya terbatas pada pemeriksaan, pemutusan dan penyelesaian gugatan/tuntutan yang bener-benar menjadi wewenang PTUN saja sedangkan mengenai gugatan/tuntutan tentang hal hal yang bersifat murni sengketa dan tututan tentang hal-hal yang bersifat murni sengketa dan tuntutan hukum
perdata.Dengan demikian setelah dibentuknya UU AP terjadi perluasan elemen objektum litis kompetensi PTUN dan lebih tepatnya perluasan element KTUN dalam UUPeratun, artinya segala sengketa administrasi negara terlebih dahulu diperiksa melalui PTUN. Peralihan kewenangan penyelesaian sengketa onrechmatige overheidsdaad dari Peradilan Umum ke PTUN yang dimaksutkan dalam ketentuan Pasal 85 UU AP diatas, dipertegas dalam Surat Edaran Mahkamah Agung Nomor 4 Tahun 2016 Tentang Pemberlakuan Rumusan Hasil Rapat Pleno Kamar Mahkamah Agung Tahun 2016 Sebagai Pedoman Pelaksanaan Tugas Bagi Pengadilan, sub bagian Rumusan Hukum Kamar Tata Usaha Negara. Perubahan paradigma beracara di Peradilan Tata Usaha Negara pasca berlakunya UU AP tentang Kompetensi PTUN mengadili onrechtmatige overheidsdaad (OOD).

Sebelum sengketa diajukan ke PTUN terlebih dahulu harus ditempuh salah satu prosedur penyelesaian sengketa administrasi yang dilakukan melalui pejabat atau 
atasan pejabat serta melalui lembaga khusus diluar intansi yang bersangkutan namun masih dilingkungan eksekutif atau disebut sebagai upaya administrative. Berdasarkan Pasal 48 UU Nomor 5 tahun 1986, upaya administratif sebagai suatu proses pertama penyelesaian sengketa yang dilakukan dalam lingkungan administrasi pemerintahan sebagai akibat dikeluarkannya keputusan yang merugikan, terdiri dari upaya keberatan dan banding administrative. Upaya administrative dipergunakan manakalah peraturan yang mengatur masalah yang dipersengketakan menyediakan prosedur, keberatan dan banding administrative atau menyediakan salah satunya. Apabila tersedia kedua-duanya maka penyelesaian sengketa dilakukan terlebih dahulu melalui keberatan, kemudian apabila tidak puas dapat diajukan banding admistrative dan apabila juga tidak puas, maka barulah dapat dilanjutkan ke lingkungan PTUN. Berdasarkan petunjuk yang dikeluarkan oleh Mahkamah Agung sebagaimana termuat di dalam SEMA
Nomor 2 tahun 1991, pengajuan sengketa dilakukan melalui jalur sebagai berikut: apabila peraturan dasar tidak menyediakan saluran "banding administrative" atau dengan kata lain hanya, menyediakan prosedur "keberatan" maka sengketa administrasi tersebut langsung diajukan ke PTUN.

Dalam UU AP ketentuan mengenai upaya administrasi diatur dalam Pasal 75 menyatakan bahwa warga masyarakat yang dirugikan terhadap keputusan dan/atau tindakan dapat mengajukan upaya administratif kepada pejabat pemerintahan atau atasan pejabat yang menetapkan dan/atau melakukan keputusan dan/atau tindakan. Pasal 76 ayat (1), (2) dan ayat (3) menyatakan pula bahwa badan dan/atau pejabat pemerintahan berwenang menyelesaikan keberatan atas keputusan dan/atau tindakan yang ditetapkan dan/atau dilakukan yang diajukan oleh warga masyarakat. Dalam hal warga masyarakat tidak menerima atas penyelesaian keberatan oleh badan dan/atau pejabat pemerintahan, dapat mengajukan 
banding kepada atasan pejabat. Jikalau dalam hal warga masyarakat tidak menerima atas penyelesaian banding oleh atasan pejabat baru mereka dapat mengajukan gugatan ke PTUN.

$\begin{array}{rrrr}\text { Namun } & \text { UU AP } & \text { sendiri } \\ \text { ditemukan } & \text { adanya } & \text { ketidak }\end{array}$
konsistenan/kontradiksi pengaturan mengenai upaya administrative sebagai sarana pertama menyelesaikan sengketa antara pejabat pemerintah dengan warga masyarakat yang dirugikan terhadap keputusan yang dikeluarkan dan/atau tindakan yang dilakukan sebagaimana dinyatakan dalam Pasal 75 dan Pasal 76 ayat (1), (2) dan ayat (3) sebelumnya. Karena dalam ketentuan Pasal 76 ayat (4) menyatakan bahwa penyelesaian sengketa melalui upaya administrative hanya berkaitan dengan batal atau tidak sahnya keputusan dengan atau tanpa disertai tuntutan ganti rugi dan tuntutan administratif.

2. Tolok Ukur Pengujian Sengketa Onrechmatige OverhaidsdaadOleh PTUNSetelah Dibentuknya UUAP

\section{a. Parameter Pengujian Sengketa Onrechmatige OverhaidsdaadOleh PTUN}

Keberadaan

system pengawasan dan pengendalian dari segi hukum (yuridiscontrol) ini bertujuan untuk mengantisifasi dan memperbaiki penyimpangan terhadap penggunaan wewenang pemerintahan oleh pejabat pemerintah baik dalam bentuk deternement de pouvoir dan/atau willkeur, atau perbuatan melanggar hukum oleh pemerintah (onrechmatige overheisdaad) melalui penggunaan berbagai macam bentuk tindakan pemerintahan (bestuur handelingen) yang mengakibatkan timbulnya kerugian negara dan pada warga masyarakat dan sekaligus merupakan faktor penyebab timbulnya sengketa antara rakyat dengan pemerintah.Penentuan letak tanggungjawab hukum teradap tuntutan beban ganti kerugian yang ditimbulkan oleh tindakan pemerintahan (bestuurshandelingen) didasarkan pada teori pertanggungjawaban yaitu tanggung jawab jabatan (faute de service) dan tanggungjawab pribadi (faute de personille). Tanggungjawab jabatan ini berkaitan dengan kedudukan jabatan pemerintahan yang melekat pada 
individu (pejabat) merupakan jabatan lembaga, atau menurut Logemenn, jabatan sebagai personifikasi hak dan kewajiban memerlukan perwakilan (vertegen woordgiving). ${ }^{10}$

$$
\text { Philipus M. Hadjon, }
$$
berpendapat bahwa sumber wewenang baik dari atribusi, delegasi atau mandate menentukan siapa yang bertanggungjawab atas suatu tindak pemerintahan, khususnya berkaitan dengan tanggung jawab jabatan menyangkut masalah legalitas. ${ }^{11}$

Dalam hal wewenang diperoleh secara atribusi (wewenanag yang melekat pada suatu jabatan, baik yang diberikan oleh UUD maupun peraturan perundang undangan) letak tanggungjawab jabatan ada pada pejabat yang memperoleh wewenang tersebut, sebagaimana ditegaskan dalam Pasal 1 butir 6 UU No 5 Tanun 1986 yo UU No 9 Tahun 2004 yang menyatakan bahwa tergugat adalah badan atatu pejabat TUN yang mengeluarkan keputusan berdasarkan

10 E. Utrecht, Pengantar Hukum Administrasi Republik Indonesia, Pustaka Tinta Mas, Surabaya, 1986, h. 202

11Philipus M. Hadjon, Kaitan Hukum Administrasi dan Tata Naskah Dinas, Universitas Airlangga Surabaya, h,1 wewenang yang ada padanya. Sementara tanggung jawab hukum atas wewenang yang diperoleh dengan cara delegasi terletak pada delegatari, sebagaimana dinyatakan dalam Pasal 1 butir 6 UU No 5 Tahun 1986 yo. UU No 9 Tahun 2004 bahwa tergugat adalah badan atau pejabat TUN yang mengeluarkan keputusan berdasarkan wewenang yang dilimpahkan kepadanya. ${ }^{12}$ Sedangkan tagungjawab hukum pemberian mandat maka tanggungjawaab jabatan tidak beralih kepada penerima mandat, dalam konteks Pasal 1 butir 6 UU No 5 Tahun 1986 yo. UU No 9 tahun 2004, tergugat adalah pemberi mandate.

Berdasarkan uraian sebelumnya semua tindakan pemerintahan tidak luput dari asas "rechmatigheids van bestuur", atau "asas keabsahan dalam pemerintahan. Asas ini menjadi alternative untuk mengontrol setiap tindakan pemerintahan (bestuurshandelingen) sekaligus memberikan jaminan kepastian perlindungan hukum bagi

12Istilah teknis dilimpahkan (pelimpahan) mengandung konsep delelegasi wewenang dalam konteks adanya gugatan TUN yang digugat adalah penerima delegasi. 
pejabat pemerintah yang menyelenggarakan pemerintahan dan warga masyarakat sebagai obyek dari penyelenggaraan pemerintahan. Kriteria keabsahan setiap tindakan pemerintahan diukur berdasarkan pada keabsahan dari wewenang, prosedur dan substansi yang berdasar pada peraturan perundang undangan yang berlaku dan AUPB. ${ }^{13}$ Dengan demikian pengujian terhadap keabsahan berhubungan erat untuk memetakan letak tanggungjawab hukum dan beban ganti kerugian kepada warga masyarakat. Warga masyarakat yang dirugikan berdasar oleh perbuatan yang rechmatigeheid melekat kesalahan jabatan (faute de service) dan melekat pada tanggung jawab dan tanggung gugat jabatan, ${ }^{14}$ yang timbul karena tindakan seseorang yang dalam rangka pelaksanaan urusan dan tugas

13 Indroharto, Usaha Memahami Undang-Undang Tentang Peradilan Tata Usaha Negara(Buku 1 Beberapa Pengertian Dasar Hukum Tata Usaha Negara), Pustaka Sinar Harapan, Jakarta, 1993, h. 52

14Tatiek Sri Djatmiati, Perizinan Sebagai Instrumen Yuridis Dalam Pelayanan Publik, Pidato, Disampaikan pada Pengukuan Jabatan Guru Besar dalam bidang hukum administrasi pada Fakultas Hukum Universitas Airlangga di Surabaya pada hari sabtu tanggal 24 November, 2007, h. 20 jabatan(ambtelijke $\quad$ handeling). ${ }^{15}$

Dalam arti pejabat pemerintah yang melakukan tindakan atas dasar kewenangannya maupun batas-batas kebebasan bertindak (diskresi) sebagaimana ditentukan oleh UU AP, pada asanya tidak berbuat melanggar hukum (onrechmatigedaad) meskipun orang lain menderita kerugian, misalnya selama pelaksanaan tugas dan urusan jabatan masih sesuai dengan dasar-dasar kewenangan misalnya sesuai dengan program tetap (protap) atau menurut perintah atasan, dan sepanjang tidak dicampurkan dengan kepentingan pribadi yang tidak mengaburkan kemurniannya sebagai urusan dan kepentingan dinas dan lembaga maka pemeriksaan dan penilaian mengenai "kebenaran " pelaksanaan tugas dan urusan itu tunduk pada peraturan hukum, bahkan peradilan terhadap lembaga (institusi) tempat bertugas.

Sedangkan onrechmatige overheidsdaadyang terjadi karena adanya kesalahan pribadi (faute personelle) berdampak pada tanggung

15Philipus M. Hadjon, et al., Hukum Administrasi Dan Tindak Pidana Korupsi, Gadjah Mada University Press, Yogyakarta, 2011, h. 94 
jawab dan tanggung gugat pribadi. ${ }^{16}$ Kesalahan pribadi (faute personelle) atau tanggung jawab pribadi berdasarkan pada perbuatan dalam urusan pribadi dan kepentingan pribadi yang dilakukan secara disengaja ataupun karena kelalaiannya maka seseorang akan melekat tanggunggugat (liability) terhadap apa yang dilakukan yang dikategorikan sebagai perbuatan maladministrasi. Dengan demikian dalam menjalankan pekerjaan jabatan secara kongkrit sangat dipengaruhi oleh kondisi pribadi seseorang (individu) yang menerima jabatan, sehingga akibat dari perbuatannya tidak semata-mata menjadi tanggungjawab dan tanggunggugat jabatannya atau lembaga, akan tetapi melekat tanggung jawab/tanggung gugat pribadi (individu/perorangan). ${ }^{17}$

\section{b. Ganti KerugianKepada Warga Masyarakat di PTUN.}

16Philipus M. Hadjon, et al., Hukum Administrasi Dan Good Governance, Universitas Trisakti, Jakarta, 2010,h. 88-91

17Sadjijono, Memahami Hukum Kepolisian, Cet ke-I, Laksbang Presindo, Yogyakarta, 2010, h. 190
Pengaturan beban gantian kerugian pada warga masyarakat yang dirugikan akibat perbuatan pemerintah yang rechmatigeheid ${ }^{l}$ sebagai tanggungjawab dan tanggung gugat jabatan pengaturannya terdapat dalam UU Peratun beserta turunannya dan UU AP. Dalam UU Peratun tuntutan ganti kerugian bersifat sanksi tambahan sebagaimana ditegaskan dalam Pasal 53 ayat (1) UU Nomor 9 Tahun 2004 tentang Perubahan UU Peratun menyatakan:

Orang atau badan hukum perdata yang merasa kepentingannya dirugikan oleh suatu keputusan tata usaha Negara dapat mengajukan gugatan tertulis kepada pengadilan yang berwenang yang berisi tuntutan agar keputusan tata usaha Negara yang disengketakan itu dinyatakan batal atau tidak sah, dengan atau tanpa tuntutan ganti rugi dan/atau rehabilitasi.

Peraturan pelaksana dari UU Peratun khusus mengenai besaran ganti kerugian yang dibebankan kepada pemerintah melalui putusan PTUN diatur dalam Peraturan Pemerintah

18 A.D. Belifante, Pokok-Pokok Hukum Tata Usaha Negara, Terjemahan, Binacipta, 1983, h. 163 
Nomor 43 Tahun 1991 Tentang Ganti Rugi Dan Tata Cara Pelaksanaannya Pada Peradilan Tata Usaha yang ditindak lanjuti dengan Keputusan Menteri Keuangan Republi $\mathrm{k}$ Indonesia

Nomor 1129/Kmk.01/1991 Tentang Tata Cara Pembayaran Ganti Rugi Pelaksanaan Keputusan Pengadilan Tata Usaha Negara, dimana Pemerintah (badan/jabatan pemerintah) melakukan ganti rugi dalam bentuk pembayaran sejumlah uang kepada orang atau badan hukum perdata atas beban badan atau jabatan administrasi berdasarkan putusan PTUNnamun dibatasi minimal hanya Rp 250.000 (dua ratus lima puluh ribu rupiah) sampai dengan maksimal $\mathrm{Rp}$ 5.000.000 (lima juta rupiah) dan hanya terhadap tuntutan ganti kerugian materil saja dan tidak untuk kerugian inmateril.

Pada dasarnya kerugian yang dialami oleh setiap warga masyarakat menjadi dasar diajukannya gugatan di PTUN namun tujuan pokoknya adalah agar PTUN membatalkan keputusan yang merugikan kepentingan warga masyarakat. Aturan tersebut memang hanya mengatur atau berisi tuntutan agar KTUN yang disengketakan itu dinyatakan batal atau tidak sah, dengan atau tanpa tuntutan ganti rugi dan/atau rehabilitasi, namun mengingat UU Peratun belum disesuaikan dengan UU AP maka aturan tersebut secara mutatis mutandis berlaku terhadap tuntutan ganti kerugian bagi warga masyarakat akibat tindakan faktual pemerintah yang absah (rechmatigeheid). ${ }^{19}$

Dalam UU AP pengaturan mengenai ganti kerugian kepada warga masyarakat akibat keputusan/tindakan faktual pemerintah yang merugikan warga masyarakat diatur dalam ketentuan Pasal 71 ayat (5) menyatakan bahwa kerugian yang timbul akibat keputusan dan/atau tindakan yang dibatalkan menjadi tanggung jawab badan dan/atau pejabat pemerintahan. Selanjutnya Pasal 72 menyatakan ketentuan mengenai tata cara pengembalian sebagaimana dimaksud dalam Pasal 70 ayat (3) dan tanggung jawab badan

19Bambang Arwanto, Perlindungan Hukum Bagi Rakyat Akibat Tindakan Faktual Pemerintah, Yuridika, Fakultas Hukum Universitas Airlangga, 2016, h 23 
dan/atau pejabat pemerintahan akibat kerugian yang ditimbulkan dari keputusan dan/atau tindakan sebagaimana dimaksud dalam Pasal 71 ayat (5) diatur dalam Peraturan Pemerintah.

Sebelumnya mengenai pengaturan ganti kerugian akibat keputusan/tindakan pemerintah yang rechmatigeheid diatur dalam RUU AP dalam Pasal 41 menyatakan:

1) Pencabutan pembatalan dan/atau keputusan terhadap pemerintahan wajib memuat ganti rugi kepada pihak yang dirugikan dan disertai dengan penyerahan kembali keputusan yang dibatalkan beserta dokumen dan/atau arsip yang terkait.

2) Besarnya ganti rugi sebagaimana dimaksud pada ayat (1) wajib memenuhi unsur keadilan dan kelayakan;

3) Pejabat administrasi pemerintahan atau badan menetapkan besarnya ganti rugi sebagaimana dimaksud pada ayat (2).

Berdasarkan penjelasan Pasal 41 ayat (2) dinyatakan bahwa keadilan dan kelayakan adalah sebanding dengan kerugian yang ditimbulkan akibat keputusan administrasi pemerintahan. Prinsip ganti kerugian dalan Pasal 41 ayat (2) RUU AP senyatanya tidak dianut dalam UU AP maupun dalam UU Peratun sebelumnya yang mengurangi pemberian jaminan perlindungan bagi warga masyarakat secara adil dan maksimal akibat tindakan pemerintah (bestuurshandelingen). Hal ini didasarkan karena pengaturan ganti kerugian dalam UU AP dan UU Peratun beserta peratun pelaksanaanya nampak tuntutan ganti kerugian menjadi tuntutan tambahan yang sifatnya fakultatif dan nilainya sangat terbatas yang berbeda dari semangat ganti kerugian dan berdasarkan keadilan dan kelayakan sebagaimana dicantumkan dalam RUU AP sebelumnya.

\section{KESIMPULAN DAN SARAN}

\section{Kesimpulan}

Dengan dibentuknya UUAP adanya perubahanobjektum litis kewenangan PTUN dalam 
menyelesaikan sengketa perbuatan melanggar hukum oleh pemerintah (Onrechmatige Overheidsdaad) yang sebelumnya adalah KTUN berdasarkan UUPeratun menjadi KTUN berdasarkan UUAP yang didalamnya termasuk pula tindakan faktual pemerintah (feitelijke handelingen)yang menimbulkan kerugian bagi Warga Masyarakat. Tolok ukur pengujian sengketa perbuatan melanggar hukum oleh pemerintah (Onrechmatige Overheidsdaad) di PTUN berdasarkan pada asas rechtsmatigeheid van bestuursyang didasarkan pada keabsahan tindakan pemerintahan (wewenang, prosedur dan substansi) berdasar pada peraturan perundang undangan yang berlaku dan AUPB.

\section{Saran}

Diperlukan peraturan pelaksana yang mengatur mengenai kewenangan PTUN menyelesaikan sengketa perbuatan melanggar hukum oleh Pemerintah (onrechmatige overheidsdaad) dengan mengingat perubahan objektum litiskompetensi
PTUN termasuk pula tolok ukur pengujian perbuatan melanggar hukum pemerintah (onrechtsmatige Overheidsdaad) di PTUN.

\section{DAFTAR PUSTAKA}

A.D. Belifante, Pokok-Pokok Hukum Tata Usaha Negara, Terjemahan, Binacipta, 1983.

Bambang Arwanto, Perlindungan Hukum Bagi Rakyat Akibat Tindakan Faktual Pemerintah, Yuridika, Fakultas Hukum Universitas Airlangga, 2016

Djenal Hoesen Koesoemahatmadja, PokokPokok Hukum Tata Usaha Negara, Bandung, Citra Aditya Bakti, 1990;

E. Utrecht, Pengantar Hukum Administrasi Republik Indonesia, Pustaka Tinta Mas, Surabaya, 1986;

Indroharto, Usaha Memahami UndangUndang Tentang Peradilan Tata Usaha Negara(Buku 1 Beberapa Pengertian Dasar Hukum Tata Usaha Negara), Pustaka Sinar Harapan, Jakarta, 1993;

Kuntjoro Purbobronoto, Beberapa Catatan Hukum Tata Pemerintahan Dan Peradilan Administrasi Negara, Cet ke-2, Alumni Bandung, 1978;

Paulus Effendi Lotulung, Lintasan Sejarah Dan Gerak Dinamika Peradilan 
Tata Usaha Negara (PERATUN),

Salemba Humanika, Jakarta, 2013;

Peter Mahmud Marzuki, Penelitian Hukum,

Kencana Prenada Media Group,

Jakarta, 2005;

Philipus M. Hadjon, Perlindungan Hukum

Bagi Rakyat di Indonesia,

Peradaban, Surabaya, 2007;

-;Kaitan Hukum Administrasi dan

Tata Naskah Dinas, Universitas

Airlangga Surabaya;

; et al., Hukum Administrasi Dan

Good Governance, Universitas

Trisakti, Jakarta, 2010;

;, et al., Hukum Administrasi Dan

Tindak Pidana Korupsi, Gadjah

Mada University Press, Yogyakarta,

2011;

Tatiek Sri Djatmiati, Perizinan Sebagai

Instrumen Yuridis Dalam

Pelayanan Publik, Pidato,

Disampaikan pada Pengukuan

Jabatan Guru Besar dalam bidang hukum administrasi pada Fakultas Hukum Universitas Airlangga di Surabaya pada hari sabtu tanggal 24 November, 2007;

Sadjijono, Memahami Hukum Kepolisian,

Cet ke-I, Laksbang Presindo, Yogyakarta, 2010; 